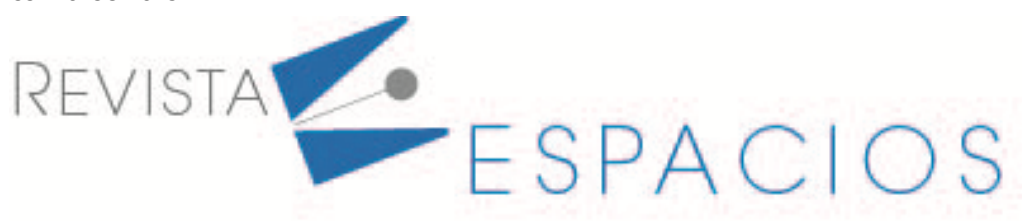

Vol. 41 (45) $2020 \cdot$ Art. 28

Recibido/Received: 27/08/2020 • Aprobado/Approved: 24/10/2020 • Publicado/Published: 26/11/2020

\title{
Peace in Colombia, at any cost?!
}

\section{¿¿Paz en Colombia, a cualquier costo?!}

\author{
MUÑOZ CARDONA, Ángel Emilio ${ }^{1}$ \\ MARTÍNEZ SOTO, Lorena ${ }^{2}$
}

\begin{abstract}
"When you realize that to produce you need to obtain authorization from those who do not produce anything; when you see that money flows to those who do not traffic with goods but with favors; when you perceive that many get rich by bribery and influences rather than by their work, and that the laws do not protect you against them but, on the contrary, they are the ones who are protected against you; when you discover that corruption is rewarded and honesty becomes self-sacrifice, then you can affirm, without fear of being wrong, that our society is doomed"
\end{abstract}

Alissa Zinovievna Rosenbaum (1950)

\begin{abstract}
Our purpose is to demonstrate: why it is important to maintain citizen faith in their justice institutions. Peace accords cannot be associated with a weakening of criminal justice. Hence the research question: how to strengthen Colombian justice in the peace accords? Colombia is not a failed state forced to sign any peace agreement. The research observes that Colombia is a democratic state with weak public values. This forces us to look for new models of participation: more plural and democratic.
\end{abstract}

key words: Legal justice, public values, social cost, peace agreements.

\section{Resumen}

Nuestro propósito es demostrar: por qué es importante mantener la fe ciudadana en sus instituciones de justicia. Los acuerdos de paz no pueden asociarse con un debilitamiento de la justicia penal. De ahí la pregunta de investigación: ¿cómo fortalecer la justicia colombiana en los acuerdos de paz? Colombia no es un estado fallido obligado a firmar ningún acuerdo de paz. La investigación observa que Colombia es un estado democrático con valores públicos débiles. Esto nos obliga a buscar nuevos modelos de participación: más plurales y democráticos.

Palabras clave: Justicia jurídica, valores públicos, costo social, acuerdos de paz.

\section{Introduction}

Valencia and Frances Gomez to say inthe article: "The agreement with the FARC. A review of its usefulness "(2018), that Colombia is a failed State condemned to celebrate any peace agreement for the good of its society.

\footnotetext{
${ }^{1}$ Economist from the University of Antioquia, Specialist in Public Sector Economics from the Autonomous University, Master in Political Philosophy from the University of Antioquia. Doctor of Political Philosophy from the University Bolivarian Pontifical, Doctor of Canonical Philosophy from the University Bolivarian Pontifical. Post doctor Public Economics of the Vrije Universiteit Amsterdam. Professor and researcher at the Superior School of Public Administration of Antioquia. e-mail angel@esap.gov.co.

2 Business Administrator of the Adventist University Corporation, Specialist in Management of Organizations of the UNAC, Master in Administration Sciences of the EAFIT University, PhD student in Organizational Studies of the Metropolitan Autonomous University of Mexico. Professor and researcher at the Adventist University Corporation. E-mail loremar@unac.edu.co.
} 
Affirmation that does not agree with the institutional character in the political and economic that has one of the best countries in Latin America and the Caribbean. Hence, the need to start this article by demonstrating that Colombia is not a failed State condemned to accept any kind of peace agreement, how as stated it Muñoz Cardona in: "The peace dialogues in Colombia, a view from the justice of compensation" (2017)and "The Justice and the Colombia Peace Talks" (2016).

Although it is true that in recent years Colombian justice institutions have reached high levels of discredit in: Judicial System of $79 \%$, Congress of the Republic of $72 \%$ and the Supreme Court of Justice with $60 \%$ ( Hernández, 2019; Colombia2020, 02/11/2020). Colombia for the last 100 years has been a country with high political stability. A democratic state that throughout its history has been able to overcome the onslaught of communism in the mid-20th century; to the armed groups outside the law and drug trafficking in the late twentieth century. It is even a country that, although it had a military government for four years (1953-1957), did not become a victim of the excesses of dictatorships.

Colombia has been an attractive country for direct foreign investment, to the point of being classified by the Economic Commission for Latin America and the Caribbean as the fourth most important destination in Latin America (ECLAC, 2019). In the course of the 21st century in Colombia, unlike other Latin American countries, have not been promoted public policies of nationalization of companies, nor has freedom of the press or expression been prohibited. Even from 2017 to 2020 it has hosted more than a million and a half Venezuelan, Salvadoran and Nicaraguan immigrants who have found in Colombia an opportunity to improve their economic living conditions. In other words, despite the discredit that its political and justice institutions currently have, Colombia is a viable country. How to recover, then, the legal institutions? How to achieve responsible citizens or those more committed to social good?

Based on the logical-deductive method of analysis for perfectly competitive markets, the authors develop an ethical model of public elections, it is capable of recovering the political institutions. To achieve this, it is necessary: first, to separate the concepts of tolerance and justice. Tolerance from a field of social responsibility, forces us to think as citizens about what is and is not tolerable, about what strengthens or weakens us in the social order. This reflection will be made from the Spanish philosophers Victoria Camps and Esperanza Guisan Seijas, the latter from the philosophical current of contemporary utilitarianism, clearly exposed in his work La ethics looks to the left (2004). Second, the principles of Adam Smith's compensation justice are taken up, which serves as a corollary to the strengthening of his central thesis "man is a moral mirror for man". Third, under this Smithian concept, the peace process in Colombia and its possible future social costs will be analyzed.

The essay concludes with the formulation of a model for strengthening democracy. A model that encourages the generalized knowledge of development plans and delves into the citizen awareness of the social good or in the joint responsibility of what is good for all. Contemporary democracy not just is to go to vote for what we particularly think, the democracy of the 21st century requires co-responsibility, the citizen's union to stop corruption and the lack of ethics of officials, as stated it (Muñoz Cardona, 2018, p. 70). Transparency, as well as honesty does not depend on the ethics of the servant or the public official, it depends on the citizen oversight, that is, on the social ethic that does not allow, in the words of Guisan Seijas, any objectification of the human beings, in other words that the push they to live worthless lives (Guisan, 2004, p. 47).

\section{Investigation methodology}

The research follows a logical-deductive historical analysis based on two bibliographic sources. On the one hand, following international theoretical sources on jurisprudence. On the other hand, following the newspaper's archival reports on the peace accords in Colombia from 2015 to 2020. These results were compared with other peace accords achieved in the 21st century in countries of Europe and Latin America. 
This research has resulted in two publications in international journals, they are: The Justice and the Colombian peace talks (DOI 10.4236 / OJPS.2016.63024) and the Social costs of peace dialogues in Colombia. A look from the justice of compensation (DOI $10.15304 / \mathrm{t} .21 .2 .3265$ ). In this latest publication, the authors of the Metropolitan Autonomous University of Mexico and the Superior School Public Administration of Antioquia propose a popular election model based on the concepts of classical economic liberalism for free competition markets. The model serves to strengthen democracy and public values in Colombia, Latin America and the rest of the world.

\section{Colombia, a failed state?}

Given the argument of Andrea Valencia and Pedro Frances Gomez: "(...) in Colombia, the only thing that can be ventured is to provoke a reconciliation and obtain some compensation from the offender for the offended, which allows the depuration of the acts committed in the context of a weak state. " (2018, p. 22). The Index of state weakness of Rice and Patrick (2018) defines the weak state as one that lacks statehood, that is, the ability to fulfill its legal functions and basic security for its citizens. It is a State incapable of legally regulating or controlling local deteriorations in the daily life of the country, which are growing more and more throughout the territory.

Although there are municipalities in Colombia where the risks of violence are stronger than in others, it is not possible to affirm that in Colombia the security and justice forces have lost control of the country. Violence in Colombia is focused on some municipalities, but there is an institutional presence with wide social acceptance. In almost all countries of the world, there are places more insecure than others, that is, where violence is more prone. Only in this, is the criticism of the Colombian State of Valencia and Frances-Gomez (2018) are right. Therefore, it is not possible to affirm that Colombia suffers from the phenomenon of uncontrolled violence; not even in the five years of Rojas Pinilla's military government as a result of the revolts generated by the death of Jorge Eliecer Gaitan in 1948 to 1953.

García M. (2018) adds to the costs of the peace dialogues with the guerrilla organization FARC the social demoralization. In other words, the relative loss of trust and faith citizen in the institutions of legal justice, as evidenced (Muñoz Cardona, 2016; 2017b) in his writings on the peace talks in Colombia. For García, such legal demoralization accompanied by the discredit of the political classes can condemn Colombia to a loss of values of social cohesion great, for which he recommends: the moralization of its democratic institutions, that is, join efforts for the recovery of public values (García, 2018).

Let us ask ourselves, then, can Colombia become a failed State as a result of the loss of confidence of its citizens in justice institutions? If the term Failed State is associated with countries devastated by wars (Zapata, 2014), that would not be the case for the Colombian State. Although Colombia has faced drug and guerrilla violence with greater emphasis since 1989, its political institutions has prevailed, even in the face of the threat of the Distension Zone in Caqueta in 1998. ${ }^{3}$

The beginnings of the peace talks in Colombia were due to the international events of the fall of the Berlin wall and the beginnings of Perestroika. International events the end of communism that motivated the Colombian constitutional reform of 1991. Some demobilized members of the M-19 guerrilla group participated in said constitutional reform in 1990 (Muñoz Cardona, 2014; 2016). Faced with the imminent fall of the Berlin Wall, the Colombian government began peace negotiations with the FARC in 1998, permeated by the drug trafficking and

\footnotetext{
${ }^{3}$ The municipality of San Vicente del Caguan in Caquetá served as a detente zone formed in 1998 with 42,000 square kilometers, in order to start peace processes with the guerrilla group FARC-EP.
} 
kidnapping. According to Von Der (2011), in Colombia guerrilla groups have abandoned the communist idea that more or less characterized them since 1982 and, faced with the threat of loss of financing due to the disintegration of the Soviet Union, began to finance their activities through kidnapping, drug trafficking, extortion of agricultural and mining entrepreneurs (Von Der, 2011, p. 143; Guaqueta, 2007: p. 427).

The population's complaints in Caqueta and other areas of the country for the continued rape abuses by the guerrillas against the civilian population, through undue retention of people, extortions, theft of livestock, kidnapping or human trafficking negotiations, and murders forced the government in 2002 to end the Distension Zone. During this period, the business FARC guerrilla was strengthened both economically as military terms (Castaño, 2016). However, the Colombian Military Forces returned to take control of the place, without major conflicts of destruction, he affirms (Muñoz Cardona, 2014; 2016).

Trafficking in persons by guerrilla groups and paramilitarism added to the guerrilla's union with drug trafficking and political activity dishonest, increased the number of crimes against humanity (Muñoz Cardona, 2014). This deepened the social disenchantment caused by the signing of the peace agreements of the late 1990s (Chaparro, 2002: p. 109). It was not conceivable that democratic actions by the population in support of peace initiatives, through the popular constitutional consultation in 1991, would serve to forgive crimes against humanity (Guaqueta, 2007: p. 425; Castaño, 2016).

Since the beginning of the 21st century, electoral contests and the desire of candidates to gain public image have increasingly weakened legal justice in Colombia. Hence, the political pardon granted to the guerrillas and groups outside the law for their demobilization in 1991, could not mean that justice would lose its function of administering justice with criteria of equal treatment for all. That is, its institutional moral character. (Chaparro, 2002).

It is one thing to soften prison terms for the achievement of national peace and another is total impunity with right to electoral participation (Muñoz Cardona, 2014; 2016). Political forgiveness cannot be equal to social forgiveness, and even less when there are crimes against humanity without clarification (Herrera, 2005: p.p. 8587). Called citizen to the Colombian criminal justice system that echoed, following the international event of September 11, 2001 in the United States.

For the first time in nine years, the disenchantment of Colombian citizens with government policies of forgiveness and forgetfulness ceased to be ignored for the growing international legislation against global terrorism (Von Der, 2011: p. 145). An international event that aroused national sensitivity against the practices of terrorism and motivated the end of the Distension Zone in Caguan in 2002 in Colombia (Muñoz Cardona, 2014).

Although Colombia is not a failed state in economic and social terms, it is a weak state in political maturity (Medellin, 2004). The political discussions of officials and servants public, as well as of political leaders, are of a populist nature, as read in (Barrientos, El Mundo 02/08/2019). They are more permeated by selfishness, the desire to obtain trusts through the payment of favors or purchases of political support. In Colombia, as in other countries in Latin America and Europe, political prominence and political corruption have been the source of wide social criticism and even of separatist efforts or social uprisings for the absences of the government in aid to the most disadvantaged populations.

Colombia is a Latin American State safe for foreign investment from the economic point of view and from the citizen behavior. Proof of this is the growing foreign direct investment, in other words, it is a safe country. From 2005 to 2008 FDI grew by 8,894 million US dollars, from 2011 to 2014 it doubled to more than 16,167 million dollars, from 2015 to 2017 it decreased to 11,000 and 13,800 million dollars as a result of the international economic crisis in the United States, European Union and China. Even Colombia is the fourth economy in Latin 
America and the Caribbean with the highest preference for FDI over Chile and Mexico, according to studies by ECLAC and the United Nations (ECLAC, 2019). ${ }^{4}$

Even in terms of Thomas Piketty, the behavior of the income taxes (2019). Colombia as France, the United States, the United Kingdom and Germany, has reduced the income tax from 39\% in 2008 to 30\% in 2020 in order to encourage business competition, export diversification, innovation and entrepreneurship. Facts that, like in Europe and the United States, have been the cause of great social disappointments due to the decrease in state aid to the poorest, that is, the reduction of resources that finance welfare economies. To what Piketty affirms, this has increased the concentration of capital since 2008 and is the cause of great social disillusionments in France, the United Kingdom, the United States, Germany (2019, p. 55), in Colombia and Latin America.

Now, if the term failed state is associated with countries with dictatorship governments or that oppress a sector of the population (Zapata, 2014). Colombia has never suffered government dictatorships, not even in the military government of Rojas Pinilla (Restrepo, 2011, p. 121). But, if there are in Colombia groups outside the law that have to destabilize the social order. Groups that have done great harm to the civilian population, as too has happened in developed and developing countries such as Spain, France and Ireland (Muñoz Cardona, 2014; 2016).

The existence of armed groups for outside the law that have made atrocious acts is an evil that has affected a lot countries in the world from France to the United States and from Colombia to Spain. The attacks by armed groups against civil society, although sporadic, have caused great pain, but this nations have managed to maintain civil unity. Even since 2017, Colombia is a destination country for Venezuelan, North American, Costa Rican, Ecuadorian and Salvadoran migrations. It is estimated that the country is home to more than $1,500,000$ Venezuelan immigrants in 2020, which has not been the cause of xenophobic movements, on the contrary, since the presidency of the Republic, extensive aid has been promoted to the neighboring country of Venezuela (Marín, 15/02/2019). It is also relevant to recognize that in Colombia there is freedom of opinion and of the press, fundamental base of all democracy for to fight corruption, promote citizen responsibility and democratic conscience.

However, the absence of public values jeopardizes Colombian social stability. The loss of citizen credibility in their political and justice institutions gradually undermine the social order, increase the socioeconomic costs of negotiating with armed groups due to the weak criminal justice system. It is not about being intolerant, as Victoria Camps affirm, since without the virtue of social tolerance, democracy is a delusion, because intolerance leads directly to totalitarianism (Camps, 2010, p. 94).

But where does tolerance end and permissibility begin? Is tolerance the same as total freedom of action? Although tolerance, as Camps affirms, begins in the recognition of the other, and therefore, of respect for the other, that is to say, to their nature; cannot accept it everything. Tolerance cannot be permissive because it destroys the institutions of justice by accepting everything that is criminal against the social order. Even permissive tolerance destroys education systems. It destroys trust in political institutions for the exercise of democracy.

\footnotetext{
${ }^{4}$ The main advantage that the country has is that at an international level Colombia is not a failed state due to its good economic indicators, as taught by the Fund for Peace Study Center (2019), where the country is ranked 75. The most stable states are below 50th place, the stable ones are between 50th and 60th positions. Those in danger between 60th and 90th position. Since 2013 Colombia has improved by 26 positions, that is, it tends to remain as Stable state.
} 
Tolerance is not synonymous with the absence of limits against the behavior of some groups of people within society. A limit to the social feelings of sympathy, says Smith (1997), follows from the reasonableness of tolerance. That is, from social consensus on what is and is not tolerable; of it what can and cannot be tolerated (Muñoz Cardona, 2016).

In a community where the limits of what is allowed are not clear, justice and citizen freedom are lost. Political institutions devalue their unifying power. To avoid the deterioration of political and social institutions, citizens must agree on what is socially and not condemnable, on what is and is not tolerable; in what is and is not forgivable; in what is and is not objectionable; in the social consequences of the forgiveness of certain crimes against humanity, as Smith puts it in the Lessons of Jurisprudence (1995).

The excesses of tolerance against crimes against humanity of the FARC-EP and the ELN facilitate the establishment of injustice. The social institutions created to preserve social order and citizen coexistence disappear. Control entities cease to fulfill the social function for which they were designed (Muñoz Cardona, 2016; 2017b).

The social decomposition that some Colombian regions suffer is the product of social tolerance to crimes against humanity, such as kidnapping. That is one of the greatest social and political costs that Colombia is experiencing today with the signing of the peace talks. Not having demanded the delivery of all the kidnapped. How could a democratic government negotiate the life and freedom of some and not of all? How can a democratic society call honorable men to congressmen ex-guerrilla who negotiated and decided the lives of their kidnapped for economic purposes? Even more so when many of them never appeared or were returned to their families. (Muñoz Cardona, 2016; 2017; 2017b).

The lack of political maturity and the position of the political parties in Colombia threaten the constitutionality of justice. It should not be legally acceptable, for the good of an entire society, for Colombian democratic institutions to accept electoral nomination for collegiate bodies to candidates with crimes against humanity. Social costs that in the future demoralize society, citizen coexistence, patience, honest and persevering work. What is the limit of justice and what is that of tolerance? What are the costs of the bad social example? Peace agreements with guerrilla groups are necessary, but not at any cost and, even less, if political electoral rights of public government are offered. What is democracy? Is politics a noble profession? Costs of moral loss in the trust that every citizen must maintain in their legal justice institutions. Widespread loss of confidence in democratic institutions that condemn all a society at the international discredit; as José Saramago de Sousa shows in his novels: Essay on blindness (2015) and Essay on lucidity (2016).

Finally, if the term Failed State is associated with countries victims of major natural disasters (Zapata, 2014), Colombia has come out ahead of two of the largest in the last 30 years: Armero and Mocoa, thanks to social union and solidarity characteristic of its inhabitants, even with the more than 1.5 million Venezuelan emigrants who from 2017 to 2020 have entered the country.

The Antioquia department, the second in economic importance in the country, is the leader of social union and political integration. Since 2015, more than 38 municipalities of the Department have been united under the figure of Province in order to improve administration and investment in local infrastructure. In other words, the planning of the territory around the conservation and preservation of natural water resources, following the model of the Valle de Aburra metropolitan area, which comprises 10 municipalities. Such are the cases of the Provinces of Cartama, Sinifana, Sant John, Waters, Forest and Turismo. Facts that have ostensibly improved economic growth in these municipalities. In the same way, the city of Medellín during the last 20 years of the 21st century has received international recognition in cultural innovation for its Culture Metro program, which is an award for citizen culture both for mobility and for the preservation of natural resources. 
Fernando Reyes (2015) affirms that the existence of very uneven development in some Colombian territories, facilitates the appearance of groups outside the law, But it is also true that corruption and the lack of political maturity in these municipalities generate a greater social imbalance. in other words, higher social costs of negative externality over the common good.

Although in the 2016 Plebiscite for Peace the Si, won in some municipalities victims of the armed conflict and by a very narrow margin throughout the national territory, as stated in the opinion article of Valencia and FrancesGómez (2018). In this result, the commentators did not take into account: the labor threats arising from political pressure, the purchase of votes and the notable incidence of the Catholic Church with the arrival of the Supreme Pontiff in Colombia at the same time.

$51.2 \%$ of voters said No to the Peace Agreement with the FARC. Those votes were votes of conscience (Saramago. $2015 ; 2016)$, that is, of the political and social cost that the country should face from then on. The lack of justice in the final agreement of the peace dialogues left more than half of the Colombian population unhappy. A fact that was reflected in the very low acceptance of the FARC political party in the 2018 elections and the occupation of the five seats in the Senate and Congress.

Likewise, the fact that a Special Court of Justice for Peace had been created whose members had to be previously approved by the same armed rebels, did not guarantee transparency. ${ }^{5}$ The Special Justice for Peace became more discredited in early 2018 for not complying with the principles of transitional justice of truth and nonrepetition, by not extraditing the guerrilla drug trafficker Santrich for continuing drug trafficking activities in border municipalities such as the Putumayo (Lloreda, 2019).

What is good for all of us as a society? John Stuart Mill interprets Utilitarianism (2002) as: "the achievement of the greatest possible happiness for the greatest number of possible people". Definition that revived in the 19th century moral philosophy the interest of associating public utility with general happiness, that is to say, with social welfare and quality of life in economic terms. More recently Esperanza Guisan Seijas (2004) associates utilitarianism with altruism as a result of the democratic consensus of what is reasonable in the pursuit of humanly good common goods, because it dignifies all human beings without exception. That is the importance of the questions that Guisan asks us: how to maintain a united society? In other words, how to unite individual interest with the interest of social happiness?

\subsection{The limits of social tolerance and intolerance.}

The achievement and performance of actions aimed at the general welfare is the ethical obligation of the official and the public servant at the exclusive service of the governed, thereby providing hope, trust and strengthening of democratic institutions. It is not the ethical relativism of politicking or patronized political action, as it proposes (Guisan, 2004, p. 10). It is an ethic for consensus, that is, for sympathy and social solidarity. It is an ethic that is tolerant of cultural differences or dissimilar ways of understanding and interpreting lived experiences and that helps the reasonableness of building, for the good of all, a better world. It is, in short, an ethic of public values placed at the service of intersubjective happiness.

Ethics as an invention and artifice, genuinely human so that humans, through language and sympatheia, solve their conflicts, smooth their rough edges, settle quarrels and lawsuits, fairly and equitably (...).

\footnotetext{
${ }^{5}$ The Special Justice for Peace was made up of 11 people nominated by the community and victims' organizations; and will be selected by 9 members of the National Government and the guerrillas (Agreement on the victims of the conflict, 12/15/2015, p. 15).
} 
Ethics constitutes that way of reasoning that destroys prejudices, that establishes critical criteria, that fuels the deepest revolution, is only possible from the transformation of spirits and legal-political and social structures at the same time (Guisan, 2004, pp 15, 16).

A social ethic for general happiness, built on the efforts of many, is the result of citizen consensus on the same common well-being, such is the objective of sciences of good government. It is the search for the highest good for all of society. That is, to make of all citizen responsible to others, because they have been trained to be happy with others, that is, to live within a community (Nussbaum, 2010). In other words, the promotion of acts that benefit many, and serve of social good example, in other words for strengthening good practices of the citizen morality.

In this way, Guisan (2004) associates utilitarianism with the exercise of what is reasonable because it is humanly good and it is humanly good because it dignifies us all as human beings. Thus, for example, if a man lives under minimum bearable conditions and this is accepted by all other human beings, then the value of the human being depreciates, loses value; that is what the Spanish philosopher calls the Ethics looks to the left.

In the Theory of Moral Sentiments, Adam Smith affirms, "Justice is the fundamental pillar on which rests entire social edifice and benevolence embellishes it" (1997, p. 186). For Esperanza Guisan the pillar fundamental of all society is tolerance correct. For what she advised: although it is true, politically speaking, respect for the plurality of criteria is urgent and necessary, the establishment a clear limit. "Respect for any way of life, of feeling or belief, would be exclusively naive, excessively false, and clearly dangerous" (Guisan, 2004, p. 22).

In other words, excessive social tolerance leads to the loss of democratic foundations, in other words: to general disillusionment in institutional trust, to disrespectful behavior in public debates of ideas, to forgetfulness and participatory abandonment of any form of social progress.

Tolerating the intolerable or tolerating everything, goes against all natural logic of social order; against all defense for public values of justice, solidarity, respect for difference, transparency, political honesty, responsibility, public accountability and even freedom, as stated in his work on freedom John Stuart Mill (1997) and Muñoz Cardona in the Ethics of Citizen Responsibility (2017, pp 318-342).

Excesses of tolerance go against any order that can facilitate social progress because they are anarchy itself. These contradictions will govern the institutional discredit of justice: "A certain intolerance with those who kill, raze, wound, stab, gag, kidnap, steal the public budget, impoverish or hinder the human race, it is not only ethically, but politically desirable" (Guisan, 2004, p. 23).

If in a society there is no clarity with what should be tolerable and what should not be tolerable, the institutions of justice are lost and one begins to be tolerant with those who are or have been cruel with human beings in one way or another. Such is the Colombian case with corruption and the political appointments of former guerrilla leaders who committed crimes against humanity. In other words, the amalgamation of the unacceptable becomes a landscape in society: political patronage is accepted as natural, kidnapping is justified for political purposes, atrocious crimes are left unpunished, corrupt governments are accepted and elected (Muñoz Cardona, 2017; 2018; Camps, 2010).

Although tolerance is based on universal, socially accepted principles, such as all human beings are free, worthy to be heard, to express their ideas and treaties equally. It is necessary to clarify that not all of these values can be the same because not all of them are equally tolerable. This means that one cannot do everything one, or even say it, from a socially ethical point of view (Guisan, 2004, p. 26). 
It means that my rights are also the rights of others, and therefore the freedoms of my individual actions cannot nullify the longings of others, like those of self-development, to live joyfully according to their goals from their illustrated autonomy (Guisan, 2004, p. 27). The latter means that it is the duty of every citizen, of every public and social organization, to prevent their associates from living small, monotonous, frustrated and frustrating lives. Every citizen and every government has a moral duty to encourage and help others build valuable lives; that is, humanly good lives.

No society can be tolerant, says Esperanza Guisan Seijas, with those who neglect their lives and freedom, so it is necessary for governments and social organizations to encourage better ways of a good life from politics and legality, for reasons of weight, with public praise, with certain restrictions imposed from the ethical point of view (Guisan, 2004, p. 44).

For reasons of fidelity and coherence in the defense of human dignity, every organization of rational human beings must be clear about what is and is not tolerable. From a social imperative of ethical utilitarianism, society has to become "intolerant" with those who tolerate the existence of own and foreign vexations, pedophilia, forced disappearances, gender violence, child pornography, kidnapping, xenophobia, extreme biological poverty, organ trafficking and all those practices that make man object and not subject. Even those activities that quickly destroy the environment and habitat. To which Guisan affirms:

We can all speak, equally, from a political and legal perspective. We can all live and live together according to our projects and dreams. But ethics must make it very clear that not all dreams carry the same burden of benefit for humanity, not all "ideals" and "ideologies" are equally emancipatory. Ethics must make it very clear that a society that is consistent, tolerant and plural must be intolerant of all those who kill the flower bud and do not allow all humans to achieve their flourishment (Guisan, 2004, p. 47).

Intolerance does not mean ideological totalitarianism, nor coercing the freedom of the individual that John Stuart Mill defended so much, it means the rationality of acts, conscious respect for the closest, with the others and our things nearer.

We accept the difficulty of consensus before the different points of view that are discussed when socializing a public investment project; even when talking about a family outing or when conducting scientific research. The differences in tastes and experiences help us to understand an ever-changing truth, to respect other points of view. Interdisciplinarity or the difference of opinions gives us the language, helps us to improve perceptions.

\subsection{Justice as a principle of social equity}

Adam Smith affirms in the Lessons of Jurisprudence $(1996, \mathrm{pp} 60,115)$ that, in any legal system, the highest principle is that of Justice, but its application does not always generate complacencies, because what may be fair for some, for others may not be, and it is due since it is alien to its popularity (acceptance) or unpopularity (rejection) of its recipients. Hence, within the context of a social rule of law, justice must always be imparted by an independent and legitimate body, accepted by all, as the Judiciary. Something like the impartial spectator of Adam Smith capable of preserving order from what is fair, that is, from what is good for everyone as a society (Smith, 1997).

The constitutionality of the law as a social science is par excellence the cornerstone of a democracy is one that grants and decides in justice. The justice as the highest principle of law must be applied based on the current legal system, that is, on what is agreed by all through the rules emanating from an independent corporation that enjoys full constitutionality and independence as proposed by the pyramid of the legislative body of Hans Kelsen (1995), where their expressions are translated into laws of the Republic addressed to their recipients (population) keeping the supreme good "summum bonum". As Hernán Valencia Restrepo defines it "a legal system whose 
nature is imperative attributive since it reigns or imposes on its recipients obligations or duties for the common good that are correlative to some subjective faculties or rights that it attributes to them. reason "(2007, p. 130).

Hence, that between Justice and law there is always a permanent dialectic, it cannot be better explained by the treatise writer Radbruch Gustav when he refers that "every positive law represents an unfortunate or happy trial of the realization of justice" (Valencia, 2007, p. 131). Or, as Aristotelian equity expresses it in the same sense when affirming: "the equitable and the just are the same thing and both are good, the only difference between them is that the equitable is even better. The difficulty is that the equitable, being fair, is not the legal fair, the fair it according to the Law, but is a blissful rectification of justice that is strictly legal "(Aristotle, 2017, 1137b). So, where the Law, being general, impersonal and abstract, equity must be its just measure, that is, it is worth noting what was wisely written by Professor Leibniz: "A just right is a pleonasm, an unjust right is a contradiction" (Gottfried, 1960, p. 11) and the just measure of the law is in the rationalization of the experiences that unite us and preserve us all as a society.

Although the Colombian State respects the division of its three political powers (Montesquieu. 1993, p.p. 113120 ), it could become a failed State if it allows the seats of political corruption in its legal institutions. According to the recent Gallup survey, the institutions with the greatest loss of prestige in Colombia are: "the Judicial System with a $79 \%$ negative image, Congress with $72 \%$ and the Supreme Court of Justice with $60 \% " .6$

Widespread mistrust of justice institutions caused by mismanagement of peace processes. Of course, it is due to the fact that, within the legitimacy, that is, in that intrinsic relationship between law and justice, the decisions of these corporations are corroded by the clientelist management of politics. Colombia in 2020 must risk all its institutional capacity to stop future social decompositions due to disbelief in justice. Colombia must work for the recovery of the image of its justice institutions. ${ }^{7}$

It is necessary for Colombian society to begin to forget the past of violence and move forward without resentment under the fulfillment of the three principles of comprehensiveness of the Victims Agreement: Truth, Reparation and Non-repetition. However, these principles must be demanded in their actual fulfillment and exguerrillas incorporated into civilian life must not be allowed to be political candidates or form political parties for their multiple crimes against humanity. ${ }^{8}$ Even more so when the Government did not give importance to $51.2 \%$ of the primary legislators in 2016 who said they were not in agreement with the Peace Accords signed between the FARC and the National Government.

Colombia in the peace agreements with the ELN must learn from its own experiences with the FARC, and from other countries that made peace agreements with legendary armed groups that also harmed civil society (Muñoz Cardona, 2016, 2017b), such as the ETA in Spain and IRA in Ireland. Countries that concluded agreements without weakening or delegitimizing justice institutions. Colombia, as in El Salvador, have concluded peace agreements sacrificing justice and democratic institutions (Muñoz Cardona, 2016, 2017b).

\footnotetext{
${ }^{6}$ See web address, accessed on October 10, 2019: www.larepublica.co/analisis/juan-manuel-nieves-r-534481/la-justicia-y-su-credibilidad-2772847

${ }^{7}$ The Peace Accords introduced a new judicial institution called Special Justice for Peace JEP. Whose legitimacy has been questioned. First, for the quality of the people who make it up. Second, for the legal treatment of total impunity; even against drug trafficking crimes, despite evidence provided by the Attorney General's Office and the US DEA.

${ }^{8}$ The SRT-AE-030-2019 Providence of the Special Justice for Peace acquits one of the main guerrilla leaders of the FARC from drug trafficking blames, grants him guarantees of non-extradition and returns him the seat of Congressman of the Republic of Colombia (Supreme Court of Justice Criminal Chamber, Order AP-19892019 (55395), 05/29/2019). See website: https://tenemosnoticias.com/noticia/fiscal-suprema-corte-renuncia-723769/1405967 accessed on October 10, 2019.
} 
Smith states in The Theory of Moral Sentiments: "Man is not a wolf to man, man is a moral mirror to man" (1997). Hence the importance of preserving and strengthening justice, no end in itself is fair if it undermines the common good of justice. Therefore, we admire the common good that politicians helped to build for the good of all his fellow citizens. So we affirm that justice and politics are valids social institutions. But when those who represent us in government are big criminals, what social validity does politics have as an institution? What is the example that the justice institutions given to young people, children and all those men who have worked for years for the good of society? That is the importance of the justice of compensation as a restorer of the social fabric, of moral example. It is not the law of talion, it is the law of fairness, prudence and mutual respect. The correct sympathy with what is and is not tolerable.

In the 2018 electoral campaigns, civil society made clear the non-acceptance of the FARC political party, the country did not accept being governed or represented by actors responsible for crimes against humanity. Therefore, Colombia is not a failed State; rather, it is a State with a weak representative democratic culture.

\subsection{A model for the rescue of democracy.}

If we ask ourselves how a tolerant, democracy-loving society can regain political institutions. In other words, how to counteract the political vices of politicking that lead to the existence of societies in crisis. How to avoid dishonest political competition? How can we put an end to political patronage and to the structures of electoral micro-enterprises that fuel corruption? To achieve this, it is necessary to rescue the political institutionality through the Government Programs, making them prevail over populism, demagogues, the marketing of the candidate's image, or the political endorsement of partisan machinery. Muñoz Cardona affirms in her work Ethics of Citizen Responsibility: A Path to Peace.

It is not the electoral micro enterprises, nor the demagogic competence of the candidates for public office, nor the promises of labor contracts, which should define democratic political elections. On the contrary, what should take precedence in democratic political contests is the serious study, by a group of technocrats or experts, on the viability of government projects or plans presented by different candidates for public office (2017, p. 273).

The Antioquia economist and moral philosopher propose the existence of a competitive voting market, in which the different candidates for public electoral office can present themselves with a well-structured proposal for local, regional or national development. In other words, each candidate must build your Government Plan by consulting the needs of the population, the available fiscal resources that can provide a solution through a detailed Public Investment Plan, which becomes the promise of execution. Said Government Plan must be presented in a sealed envelope without its own name, to which a code will be assigned; and in a separate envelope the personal data of the author of the proposal.

The different proposals of the candidates for the electoral public office will be evaluated by groups of technocratic experts, they will say what are the viable government programs. Said government programs will be made known to the community in public squares, will be discussed and commented in academic venues open to the entire community by experts in city science who must contribute; For this, mass media such as television, radio and web pages will be used for a period of six months. Once all viable programs have been socialized, they will be voted on. The enlightened community will decide with which or with which government programs it feels most identified. At least the 7 best Government Plans or best viable future city projects are selected and in which the candidate and the community are committed to working and supporting. After the election of the best Government Plans is finished, its proponents are made known, so that they are the ones who publicly support them, show their managerial and government skills. 
Through this mechanism of popular election, the vote wins in democracy, since it is chosen with knowledge; Political institutions in its ethical value is rescued, leaving aside political patronage and partisan machinery. Enforcement is enforced, citizen oversight is improved, and the economy is put at the service of society and not of political machineries.

However, from a methodological reflection the concern arises: what should be first for a citizen before supporting a candidate in public elections: the candidate's government program or the community development plan? That is, how does a community decide what is the best common good for it? Before choosing, among a public good $x, y, z$, the community must know what is the best good to achieve its growth and development goal. In other words, what is the design of the region they want to inhabit or live in and what community do they want to build? How do the inhabitants of this city look in 4 or 5 years? (Muñoz Cardona, 2017, p. 274).

The previous proposal merits research on a new design in social logistics for electoral purposes. A new way of seeing and understanding the art of doing politics as a promoter of social development and happiness. A participatory social action where facts are more important than words. A democracy for social happiness, and not for patronage and demagoguery. As William Ceron Gonzalez (2014) states, on the back cover of the book "Democracy or Deception: "Education must take the issue of democracy as a starting point and a benchmark in citizen training, making it an inclusion project that goes beyond the suffrage procedure" and helps the social construction of intersubjective happiness (Muñoz Cardona, 2017 , p. 274).

\section{Conclusions}

For the reconstruction of the social fabric in the new post-conflict society, Colombia urgently demands the moralization of legal and political institutions. The moral deterioration of the political parties and the absence of the ethical values of their leaders drag with them the social discomfort in justice. For the reconstruction of the Colombian post-conflict society, it is proposed:

First, to create a citizen culture of sensitivity to what should be and should not be tolerable through the use of information technologies and the support of the most prestigious university training centers.

Second, strengthening democracy through the moralization of electoral campaigns, which must be based exclusively on the promulgation of the proposals of the Government Plans.

Third, peace agreements must be made without the weakening of justice, on the contrary, they must be made with the strengthening of institutions. That is, without the alternative creation of new institutions of justice with the capacity to establish different sentencing norms or to typify crimes against humanity in another way.

Fourth, the political and justice institutions must enforce the peace agreements on the victims of the conflict, and not allow former actors of the violence of drug trafficking, paramilitarism, kidnapping and other crimes against humanity to occupy positions of public government, such as mayors, governors, presidency, congress, assembly and councils.

\section{Bibliographic references}

Agreement on the victims of the conflict. (12/15/2015). "Comprehensive System of Truth, Justice, Reparation and Non-Repetition", including the Special Jurisdiction for Peace and Commitment on Human Rights.

Aristotle. (2017). Ethics to Nicomaco. Spain: Alliance. 
Barrientos, RD. (El Mundo 08/02/2019). Stay in Venezuela, Piedad Esneda! Bogota Colombia. El Mundo newspaper, columnists. https://www.elmundo.com/noticia/-Quedese-en-VenezuelaPiedad-Esneda/377227

Camps, Victoria. (2010). "Solidarity, Responsibility, Tolerance". In Public Ethics. Merino, Mauricio, (Compiler). Mexico: Siglo XXI Editores S.A. School of Public Administration of the Federal District, p.p. 63-108

Castaño, O. Román. (2016). Injustice of justice. The sudden death of democracy and the rule of law in Colombia. Medellín: Read it.

Ceron González, William. (2014). Democracy or Deception. Medellín: Universidad Autónoma Latinoamericana, Editions UNAULA, 200 pages.

Chaparro, A. A. (2002). Political Culture and Forgiveness. Bogotá: University of Rosario.

Colombia2020. Truth and memory. (02/11/2020). "Intellectuals concerned about the direction of the National Center for Historical Memory. Bogota; El Espectador newspaper and Colombia in Transition. In association with the European Union and the Embassy of the Federal Republic of Germany in Bogotá.

ECLAC. (2019). Foreign Direct Investment in Latin America and the Caribbean. Santiago de Chile: United Nations.

Garcia, Miguel. (2018). Colombia, a failed state? Bogotá, The Portfolio (04/19/2019).

Gottfried, W. Leibniz. (1960). Three essays: law and equity. Justice. The wisdom. Mexico: Study Center of the National University.

Guisan, Seijas. Hope. (2004). Ethics look to the left. Barcelona: Anthropos

Guaqueta, A. (2007). "The Way Back in: Reintegrating Illegal Armed Groups in Colombia Then and now". London: Routledge.

Herrera, J.C. (2005). "Reconciliation and Transitional Justice: Options for Justice, Truth, Reparation and Forgiveness", Bogotá: Political Paper, No 18, December, pp. 79-112.

Hernandez, J.G. (2019). Justice is in crisis. Public Reason.com. Bogotá. Newsletter sponsored by: University of Ibague, University of EAFIT and University Externado of Colombia, https://razonpublica.com/la-justiciaesta-en-crisis/ Creative Commons License.

Kelsen, Hans. (nineteen ninety five). General theory of law and the State. Mexico: National Autonomous University of Mexico.

Lloreda, Francisco. (2019). The Special Justice for Peace of "Santrich". Bogotá: The Country. (19/05/2019)

Marín, Morales Anna. (02/15/2019). The Colombian dream: drawing the new routes. London: ROUTED Journal of (in) mobility and immigration. https://www.routedmagazine.com/colombian-dream

Medellin, Pedro. (2004). Public policies in a country with weak institutionalization. PhD thesis in Political Science. University of Paris, La Soborna.

Montesquieu. (1993). From the spirit of the laws. Barcelona: Altaya, Great works of thought.

Mill John Stuart (2002). Utilitarianism. Madrid, Spain: Editorial Alliance, Philosophy, translation by Esperanza Guisan

Mill, Stuart John. (1997). On freedom, Madrid: Editorial Alliance 
Muñoz Cardona, Á. E. (2014). "The New Public Management in Sabaneta, Antioquia". Open Journal in Political Science, Vol. 4 and No. 3, p.p. 180-194.

Muñoz Cardona, Á. E. (2016). “The Justice and the Colombia Peace Talks". United States: Open Journal the Political Science. Scientific Research Publishing

Muñoz Cardona, Á.E. (2017). Ethics of citizen responsibility: Bogotá: Higher School of Public Administration. Faculty of Research, 2nd edition, 378 pages.

Muñoz Cardona, Á. E. (2017b). The social costs of peace talks in Colombia. A look from the justice of compensation. Spain: Ibero-American Journal of Utilitarian Studies, TELOS, Vol. XXI-2, p.p. 9-39.

Muñoz Cardona, Á. E. (2018). Manual of public values for social and community organizations. A contribution from Itagüi for the Metropolitan Area, Antioquia and Colombia. City Hall of Itagüi and the Higher School of Public Administration: Secretariat for Participation and Social Inclusion.

Nussbaum, Martha. (2010). Nonprofit. Why democracy needs humanities. Buenos Aires, Argentina. Katz Editors. First edition.

Piketty, Thomas. (2019). Capital and ideology. Colombia: Ariel. Translation by Daniel Fuentes.

Restrepo, N. (2011). Antioquia entrepreneurship and society, 1940-2004: influence of Antioquia's employer elites on Colombian socioeconomic policies. Medellín: University of Antioquia, Clio Collection

Reyes, Fernando. (2015). Is Colombia a Failed State? Bogotá: RT (08/12/2015).

Rice, Susan E. y Stewart, Patick (2008). Index of state weakness in the development world. New York: The Brookings Institution.

Saramago, José. (2015,). Essay on blindness. Colombia: Disonex, S.A. Pocket Collection.

Saramago, José. (2016,). Essay on lucidity. Colombia: Disonex, S.A. Pocket Collection.

Smith, Adam. (1997). Theory of moral feelings. Madrid: Editorial Alliance. Preliminary study by Carlos Rodríguez Braun.

Smith, Adam. (1996). Lessons in Jurisprudence. Madrid. National Press of the Official State Gazette. Political Classics. Translation and preliminary study by Alfonso Ruiz Miguel.

Smith, Adam. (1995). Lessons on Jurisprudence. Granada, Spain. Comares Library of Legal Science, Los Argonautas Collection No 1.

Valencia, Paula and Frances-Gomez, Pedro (2018). The agreement with the FARC. A review around its usefulness. Spain: Ibero-American Journal of Utilitarian Studies, TELOS, Vol. XXII-1, p.p. 9-31.

Valencia, Restrepo Hernan. (2007). Nomoarchic, legal principialistics or philosophy and science of the general principles of law. Colombia: COMLIBROS

Von Der, C. (2011). "The Conflict in Colombia and the Relationship between Humanitarian Low and Human Rights law in Practice: Analyses of the New Operational law of the Colombian Armed Forces", Oxford University Press, Journal of Conflict and Security Law, vol. 16(1) pp. 141-164.

Zapata, Callejas John. (2014). The theory of the failed state between approximations and dissensions. Bogotá: New Granada University. Journal of International Relations, Strategy and Security, Vol. 9-1 p.p. 87-110.

Esta obra está bajo una Licencia Creative Commons Attribución-NoCommercial 4.0 International

(cc) BY-NC 